\title{
Efficacy and Tolerability of Once-Daily Grepafloxacin Compared with Clarithromycin in the Treatment of Acute Bacterial Exacerbations of Chronic Bronchitis
}

\author{
C. Andrew DeAbate, ${ }^{1}$ Douglas Myers, ${ }^{2}$ Dan Henry, ${ }^{3}$ John Upchurch, ${ }^{4}$ Grace Lecara, ${ }^{5}$ \\ Gregory Giguere ${ }^{5}$ and Jeffrey J. Collins 5 \\ 1 Woodmere Medical Center, Harvey, Los Angeles, California, USA \\ 2 PrimeCare, Zanesville, Ohio, USA \\ 3 Foothill Family Clinic, Salt Lake City, Utah, USA \\ 4 UAB Health Center, Birmingham, Alabama, USA \\ 5 Glaxo Wellcome Inc., Research Triangle Park, North Carolina, USA
}

\section{Abstract}

Objectives: The clinical and bacteriological efficacies and tolerability of grepafloxacin 400mg once daily for 10 days were compared with clarithromycin $500 \mathrm{mg}$ twice daily for 10 days in patients with acute bacterial exacerbations of chronic bronchitis (ABECB).

Patients and Study Design: 379 patients with signs and symptoms of ABECB were enrolled in a randomised, double-blind clinical trial conducted at 15 outpatient centres in the USA. Eligible patients were randomly assigned to receive either grepafloxacin plus matched clarithromycin placebo $(\mathrm{n}=192)$ or clarithromycin plus matched grepafloxacin placebo $(\mathrm{n}=187)$.

Results: The two treatment groups were equivalent with respect to clinical efficacy, and no statistically significant differences in the incidence of drugrelated adverse events were seen between the two groups. A satisfactory clinical outcome was achieved in $88 \%$ (130 of 148) and 89\% (134 of 150) of clinically evaluable patients treated with grepafloxacin or clarithromycin, respectively. The primary pathogens isolated from pretreatment sputum specimens were Haemophilus parainfluenzae, H. influenzae, Moraxella catarrhalis, Streptococcus pneumoniae and Staphylococcus aureus $(31,18,6,5$ and $4 \%$ of isolates, respectively). Pathogens were eradicated or presumed to be eradicated in $88 \%$ (113 of 129) and 78\% (97 of 125) of bacteriologically evaluable patients treated with grepafloxacin or clarithromycin, respectively. Both treatments were associated with a low incidence of drug-related adverse events.

Conclusion: These results indicate that grepafloxacin 400mg once daily for 10 days is as well tolerated and as clinically effective as clarithromycin $500 \mathrm{mg}$ twice daily for 10 days in patients with ABECB.

Editor's Note: This article replaces the article published in the January 1999 issue of the journal [Clin Drug Invest 1999 Jan; 17 (1): 21-31] as the data presented in the previous version were reversed for the two drugs, i.e. the data given for grepafloxacin applied to clarithromycin, and vice versa. This current article presents the correct data. 
Chronic bronchitis is an obstructive lung disease affecting an estimated $5 \%$ of the middle-aged and elderly population in the USA. ${ }^{[1]}$ Acute bacterial exacerbations of chronic bronchitis (ABECB) occur frequently in affected individuals and are characterised by increased cough and sputum production, dyspnoea and sometimes fever. ${ }^{[2]}$ Haemophilus influenzae, Streptococcus pneumoniae and Moraxella catarrhalis are major pathogens identified in ABECB. ${ }^{[3,4]}$ Antimicrobial agents directed against these pathogens play a role in preventing suppurative complications and in reducing the morbidity and mortality associated with acute bacterial infections in patients with chronic pulmonary disease. ${ }^{[2,5]}$

Patients with ABECB often receive empirical antibiotic treatment. Empirical therapy with some $\beta$-lactam and macrolide antibiotics has been compromised by the rise in incidence of penicillin resistance and $\beta$-lactamase production among the common pathogens. ${ }^{6-8]}$

The number of highly penicillin-resistant isolates of S. pneumoniae approaches $14 \%$ in the USA, while intermediate resistance is seen in $20 \%$ or more of strains, reflecting regional variability. ${ }^{[9]}$ Furthermore, the incidence of $S$. pneumoniae multiresistance is increasing, resulting in decreased susceptibility of these strains to macrolides and some other antibiotics as well. ${ }^{[9,10]}$ For example, approximately $23 \%$ of $S$. pneumoniae clinical isolates are resistant to macrolide antibiotics, and this resistance occurs primarily in strains with high level or intermediate resistance to penicillin (Glaxo Wellcome, data on file). In addition, more than $90 \%$ of $M$. catarrhalis clinical isolates and up to $40 \%$ of $H$. influenzae strains produce $\beta$-lactamases, reducing susceptibility to $\beta$-lactam antibiotics. ${ }^{[11-13]}$ Therefore, new antimicrobial agents that are well tolerated and efficacious are necessary for effective therapy in ABECB.

Grepafloxacin (Glaxo Wellcome) is a broadspectrum fluoroquinolone with greater activity against Gram-positive bacteria than first-generation quinolones, as well as excellent activity against Gram-negative and atypical organisms. ${ }^{[14,15]}$
Grepafloxacin also has demonstrated in vitro activity against penicillin-resistant $S$. pneumoniae isolates. The drug is well distributed in respiratory fluids and tissues, and its pharmacokinetic parameters permit once-daily dose administration. ${ }^{[16,17]}$ A once-daily dosage regimen of grepafloxacin is currently indicated for the treatment of lower respiratory tract infections, including $\mathrm{ABECB}$ and community-acquired pneumonia, as well as for some sexually transmitted diseases.

Clarithromycin (Abbott Laboratories) is an extended-spectrum macrolide antibiotic currently approved for use twice daily in the treatment of upper and lower respiratory tract infections including ABECB. Clarithromycin demonstrates good bioavailability and tissue distribution. ${ }^{[18]}$

The present study was undertaken to compare the tolerability and efficacy of grepafloxacin $400 \mathrm{mg}$ once daily for 10 days with clarithromycin $500 \mathrm{mg}$ twice daily for 10 days in the treatment of patients with ABECB.

\section{Patients and Methods}

This study (protocol number GFXA4001) was a double-blind, multicentre, randomised clinical trial conducted at 15 outpatient or private practice centres throughout the USA. All patients provided written informed consent prior to entry in the study, and the study protocol was approved by all Institutional Review Boards in accordance with FDA guidelines.

\section{Patient Selection}

Male and female outpatients aged 18 years or older were eligible to participate in the study if they had an established diagnosis of chronic bronchitis (defined as the daily production of sputum during 3 consecutive months for greater than 2 successive years) and if the onset of exacerbated symptoms was within 14 days prior to enrolment. Eligible patients displayed signs and symptoms at enrolment compatible with ABECB, consisting of three or more of the following six symptoms: increased frequency and/or severity of cough; increase in sputum volume; purulent changes in sputum; dys- 
pnoea or increased dyspnoea; increased chest congestion as indicated by adventitious sounds, and chills and/or fever.

Patients were not eligible if a chest $x$-ray taken within 48 hours prior to enrolment indicated the presence of pneumonia as evidenced by new localised infiltrate, pleural effusion or consolidation.

Patients were excluded from the study if they presented with a history of hypersensitivity or phototoxicity reaction to any quinolone or macrolide antibiotic. Patients presenting with the following conditions or diseases were excluded from participation in the study: neutropenia, immune deficiency, AIDS, severe uncontrolled diabetes mellitus, significant heart disease, hepatic disease, splenectomy, concomitant respiratory disease, seizure disorders or gastrointestinal disease affecting absorption of antibiotics.

Exclusion criteria also consisted of concomitant therapy with theophylline, warfarin or any oral anticoagulant, systemic corticosteroids, carbamazepine, ketoconazole, digoxin, ergotamine, dihydroergotamine, triazolam, cisapride, astemizole, terfenadine, alfentanil, bromocriptine, cyclosporin, disopyramide, fluconazole, hexobarbital, lovastatin, omeprazole, phenytoin, pimozide, valproic acid and zidovudine. Patients were excluded if they had received any systemic antimicrobial agent within the previous 7 days or had failed prior treatment for the current ABECB. Female subjects were excluded if they were pregnant or lactating or were of childbearing potential and not using approved methods of contraception.

\section{Microbiological Investigations}

A sputum specimen for culture was obtained within 48 hours before starting treatment. Sputum specimens were examined by Gram stain, and only specimens containing $\geq 25$ polymorphonuclear leucocytes/low power field were considered acceptable. Sputum specimens were shipped to a central laboratory (Covance, Indianapolis, IN) and the infecting organisms were identified and tested for susceptibility to grepafloxacin and clarithro- mycin (all S. pneumoniae isolates were also tested for penicillin susceptibility) via a tube or agar dilution minimum inhibitory concentration determination using breakpoints established by the National Committee for Clinical Laboratory Standards. ${ }^{[19,20]} \beta$-Lactamase production was determined for all Haemophilus species and M. catarrhalis isolates using a nitrocefin base test.

\section{Antimicrobial Therapy}

Eligible patients were randomly assigned to receive either grepafloxacin $400 \mathrm{mg}$ once daily (plus matched clarithromycin placebo) or clarithromycin 500mg twice daily (plus matched grepafloxacin placebo) for 10 days. Study medication was administered without regard to meals, although patients were advised to avoid taking medication concurrently with large amounts of caffeine-containing foods or beverages. Products containing iron or zinc, multivitamin preparations, antacids and sucralfate were not to be taken within 2 hours before or 2 hours after taking study medication. Concurrent treatment with these products was discouraged throughout the treatment period. A urine specimen $(>10 \mathrm{ml})$ was obtained 4 to 6 days after the start of treatment and assessed by a biological assay for the presence of antibiotic in order to confirm compliance with therapy.

\section{Clinical and Bacteriological Evaluations}

Patients were evaluated for clinical symptoms and physical signs of infection 4 to 6 days after starting treatment (during-treatment visit), 1 to 3 days after treatment (end-of-treatment visit), and 21 to 24 days after treatment (follow-up visit). Clinical assessments were made on the basis of frequency and/or severity of cough, volume of sputum production, qualitative changes in sputum purulence, dyspnoea, chest congestion, and chills and/or fever (oral temperature $\geq 100.0^{\circ} \mathrm{F}$ or $\geq 37.8^{\circ} \mathrm{C}$ ).

The clinical response at the time of withdrawal or at the follow-up visit for all cases was classified by the investigator as: 
- cure (clinical signs and symptoms of ABECB improved or resolved at the 1- to 3-day posttreatment visit and were absent at the 21- to 24day post-treatment visit);

- improvement (improved but with incomplete resolution of the clinical signs and symptoms of $\mathrm{ABECB}$ by the 21- to 24-day post-treatment visit);

- failure (no apparent response to treatment after 3 or more days of therapy, or patient withdrawn because of a study drug-related adverse event);

- recurrence (resolution or improvement of clinical signs and symptoms of ABECB at the 1- to 3 -day post-treatment visit with recurrence of clinical symptoms by 21 to 24 days post-treatment).

Study patients were considered clinically unevaluable if they received concomitant treatment with a non-study systemic antimicrobial agent, received less than 3 days of treatment with the study drug, failed to complete all scheduled study visits, showed evidence of poor compliance, withdrew from the study because of a non-study drug-related adverse event, were enrolled in violation of the selection criteria, or deviated significantly from the study protocol in any other way.

Bacteriological response to treatment was defined as:

- cure (initial pathogen eradicated during or at completion of therapy);

- presumed cure (culturable material not available at the during- or post-treatment visits as a result of clinical improvement);

- failure (initial pathogen still present after at least 3 days of therapy without eventual clearance);

- presumed failure (culturable material not available and the patient was discontinued from the study with an unsatisfactory clinical response);

- recurrence (eradication and then reisolation of the initial pathogen);

- cure with colonisation (eradication of initial pathogen plus isolation of at least one new nonpathogen not associated with clinical symptoms);
- cure with superinfection (eradication of initial pathogen plus isolation of one or more new pathogens);

- failure with superinfection (no eradication of initial pathogen plus isolation of one or more new pathogens); or

- failure with resistance [bacteriological failure as defined above with initial pathogen(s) developing resistance to study drugs during the course of therapy].

In cases where more than one organism was isolated from a single sample, each pathogen was evaluated separately. A study patient was considered bacteriologically unevaluable if the patient was clinically unevaluable or if there was inability to culture a pretreatment bacterial pathogen. Patients with negative pretreatment cultures remained in the study for the evaluation of clinical efficacy.

\section{Tolerability Assessment}

Blood was collected for haematology and clinical chemistry testing at the enrolment and 1- to 3-day post-treatment visits. No clinical chemistry or haematology testing was performed at the during-treatment or 21- to 24-day post-treatment visits unless abnormalities were noted in the sample collected at the previous visit. At each visit, adverse events determined by spontaneous patient reports and/or nonsuggestive questioning were assessed by investigators for severity, frequency, outcome and potential relationship to study drug.

\section{Statistical Analyses}

The primary study end-point was the satisfactory clinical response rate (cure plus improvement) in the clinically evaluable patient population. The trial was designed to test for statistical equivalence between the grepafloxacin and clarithromycin treatment groups. For satisfactory outcomes $\geq 80 \%$ and $<90 \%$, treatment equivalence was established if the lower limit of the $95 \%$ confidence interval (CI) around the difference in response rates was greater than or equal to $-15 \%$ and if the confidence interval included the value of zero. A sample size of 300 clinically evaluable patients was adequate 
to establish treatment equivalence with the assumption that the observed treatment difference would be no more than $6 \%$.

Secondary end-points were the satisfactory bacteriological outcome (cure, presumed cure and cure with colonisation) in the microbiologically and clinically evaluable population and incidence of adverse events. Other efficacy measures included a subgroup summary of age, gender and race to informally compare the rates of satisfactory clinical response between treatment groups at the follow-up assessment.

A 2-tailed Fisher's exact test was used to compare differences between treatment groups in clinical and bacteriological efficacies and incidences of the most common drug-related adverse events (defined as an incidence of the specified adverse event of 5\% or greater in any group). All tests were 2 -sided and values less than 0.05 were considered significant.

\section{Results}

Three hundred and seventy-nine patients with chronic bronchitis were enrolled in the study, of which 192 were randomised to receive grepafloxacin and 187 were randomised to receive clarithromycin. Demographic characteristics between groups were comparable (table I). Clinical symptoms at enrolment occurred with similar frequency in both treatment groups (table II). Two patients in the clarithromycin group were considered unevaluable since their pretreatment chest radiographs revealed lobar consolidation. Neither lobar infiltrate nor pleural effusion was present in any patient enrolled in the study.

The median dosage duration was 10 days for both treatment groups, while the mean dosage duration was 9.8 and 9.9 days for the grepafloxacin and clarithromycin groups, respectively. Good compliance was seen at the 4- to 6-day duringtreatment visit with both treatment regimens; antibiotic activity was detected in the urine of 175 of 192 (91\%) and 176 of 187 (94\%) patients receiving grepafloxacin or clarithromycin, respectively.
Table I. Summary of demographic characteristics of study patients

\begin{tabular}{lcc}
\hline & $\begin{array}{c}\text { Grepafloxacin } \\
(10 \text { days }) \\
{[\mathrm{n}=192]}\end{array}$ & $\begin{array}{l}\text { Clarithromycin } \\
(10 \text { days }) \\
{[\mathrm{n}=187]}\end{array}$ \\
\hline Gender [no. (\%)] & $100(52 \%)$ & $109(58 \%)$ \\
$\quad$ Male & $92(48 \%)$ & $78(42 \%)$ \\
$\quad$ Female & & \\
Ethnic origin [no. (\%)] & $138(72 \%)$ & $138(74 \%)$ \\
Caucasian & $48(25 \%)$ & $44(24 \%)$ \\
Black & $2(1 \%)$ & $3(2 \%)$ \\
Hispanic & $4(2 \%)$ & $2(1 \%)$ \\
Asian & & \\
Age (y) & $47.3 \pm 1.1$ & $49.9 \pm 1.1$ \\
Mean \pm SEM & $18.4-90.6$ & $18.8-85.0$ \\
Range & & \\
Weight (kg) & $80.8 \pm 1.4$ & $79.7 \pm 1.4$ \\
Mean \pm SEM & $46.3-149.4$ & $44.0-164.8$ \\
Range & &
\end{tabular}

\section{Clinical Outcome}

Table III presents the clinical outcome of patients in the two treatment groups. Of the 379 patients enrolled, 298 (79\%) were clinically evaluable. Of the 81 clinically unevaluable patients, 27 (7\%) were lost to follow-up, $16(4 \%)$ had enrolment violations, 15 (4\%) failed to complete study visits, $9(2 \%)$ withdrew either because of a nonstudy drug-related adverse event or for reasons not related to adverse events, and 14 (4\%) had other protocol violations. A satisfactory clinical response (cure or improvement) was obtained in 88 and $89 \%$ of clinically evaluable patients treated with grepafloxacin or clarithromycin, respectively, and equivalence was established through $95 \% \mathrm{CI}$ analysis.

Patients in both treatment groups demonstrated marked improvement at the first during-treatment measurement ( 4 to 6 days after initiation of therapy), and continued to improve throughout the study, as judged by the reduction in the proportion of patients with clinical symptoms of ABECB, as well as by the substantial decreases in the severity of the symptoms that were present (table II and fig. 1). The incidence of severe productive cough decreased from $29 \%$ in both groups at enrolment to $5 \%$ in the grepafloxacin group and $3 \%$ in the 
Table II. Clinical symptoms of patients with acute bacterial exacerbations of chronic bronchitis in the intent-to-treat population at time of enrolment, 4 to 6 days after initiation of treatment (during-treatment visit) and at 1 to 3 days (end-of-treatment visit) and 21 to 24 days (follow-up visit) after treatment

\begin{tabular}{|c|c|c|c|c|c|c|c|c|c|}
\hline \multirow[t]{2}{*}{ Symptom } & \multirow[t]{2}{*}{ Severity } & \multicolumn{2}{|l|}{ At enrolment } & \multicolumn{2}{|c|}{ During-treatment visit } & \multicolumn{2}{|c|}{ End-of-treatment visit } & \multicolumn{2}{|l|}{ Follow-up visit } \\
\hline & & $\begin{array}{l}\text { grepafloxacin } \\
10 \text { days } \\
{[n=192]}\end{array}$ & $\begin{array}{l}\text { clarithromycin } \\
10 \text { days } \\
{[n=187]}\end{array}$ & $\begin{array}{l}\text { grepafloxacin } \\
10 \text { days } \\
{[n=185]}\end{array}$ & $\begin{array}{l}\text { clarithromycin } \\
10 \text { days } \\
{[n=181]}\end{array}$ & $\begin{array}{l}\text { grepafloxacin } \\
10 \text { days } \\
{[n=171]}\end{array}$ & $\begin{array}{l}\text { clarithromycin } \\
10 \text { days } \\
{[n=170]}\end{array}$ & $\begin{array}{l}\text { grepafloxacin } \\
10 \text { days } \\
{[n=154]}\end{array}$ & $\begin{array}{l}\text { clarithromycin } \\
10 \text { days } \\
{[n=156]}\end{array}$ \\
\hline \multirow[t]{5}{*}{ Productive cough } & Mild & $12(6 \%)$ & $11(6 \%)$ & $99(54 \%)$ & $124(69 \%)$ & $119(70 \%)$ & $118(69 \%)$ & $90(58 \%)$ & $84(54 \%)$ \\
\hline & Moderate & $125(65 \%)$ & $122(65 \%)$ & $61(33 \%)$ & $39(22 \%)$ & $15(9 \%)$ & $4(2 \%)$ & $8(5 \%)$ & $8(5 \%)$ \\
\hline & Severe & $55(29 \%)$ & $54(29 \%)$ & $9(5 \%)$ & $5(3 \%)$ & $2(1 \%)$ & $2(1 \%)$ & $3(2 \%)$ & $2(1 \%)$ \\
\hline & Total & $192(100 \%)$ & $187(100 \%)$ & $169(91 \%)$ & $168(93 \%)$ & $136(80 \%)$ & $124(73 \%)$ & $101(66 \%)$ & $94(60 \%)$ \\
\hline & Absent & 0 & 0 & $16(9 \%)$ & $13(7 \%)$ & $35(20 \%)$ & $46(27 \%)$ & $53(34 \%)$ & $62(40 \%)$ \\
\hline \multirow{5}{*}{$\begin{array}{l}\text { Increased sputum } \\
\text { production }\end{array}$} & Mild & $12(6 \%)$ & $18(10 \%)$ & $111(60 \%)$ & $114(63 \%)$ & $114(67 \%)$ & $106(62 \%)$ & $83(54 \%)$ & $72(46 \%)$ \\
\hline & Moderate & $149(77 \%)$ & $131(70 \%)$ & $52(28 \%)$ & $38(21 \%)$ & $12(7 \%)$ & $6(4 \%)$ & $9(6 \%)$ & $8(5 \%)$ \\
\hline & Severe & $31(16 \%)$ & $38(20 \%)$ & $7(4 \%)$ & $7(4 \%)$ & $2(1 \%)$ & $2(1 \%)$ & $3(2 \%)$ & $1(<1 \%)$ \\
\hline & Total & $192(100 \%)$ & $187(100 \%)$ & $170(92 \%)$ & $159(88 \%)$ & $128(75 \%)$ & $114(67 \%)$ & $95(62 \%)$ & $81(52 \%)$ \\
\hline & Absent & 0 & 0 & $15(8 \%)$ & $22(12 \%)$ & $43(25 \%)$ & $56(33 \%)$ & $59(38 \%)$ & $75(48 \%)$ \\
\hline \multirow{5}{*}{$\begin{array}{l}\text { Purulent change in } \\
\text { sputum }\end{array}$} & Mild & $18(9 \%)$ & $20(11 \%)$ & $93(50 \%)$ & $102(56 \%)$ & $33(19 \%)$ & $27(16 \%)$ & $20(13 \%)$ & $13(8 \%)$ \\
\hline & Moderate & 147 (76\%) & $132(71 \%)$ & $40(22 \%)$ & $29(16 \%)$ & $4(2 \%)$ & $3(2 \%)$ & $4(3 \%)$ & $6(4 \%)$ \\
\hline & Severe & $24(13 \%)$ & $34(18 \%)$ & $2(1 \%)$ & $1(<1 \%)$ & $2(1 \%)$ & $1(<1 \%)$ & $1(<1 \%)$ & 0 \\
\hline & Total & 189 (98\%) & 187 (99\%) & $135(73 \%)$ & $132(73 \%)$ & $39(23 \%)$ & $31(18 \%)$ & $25(16 \%)$ & $19(12 \%)$ \\
\hline & Absent & $3(2 \%)$ & $1(<1 \%)$ & $50(27 \%)$ & $49(27 \%)$ & $132(77 \%)$ & $139(82 \%)$ & $129(84 \%)$ & 137 (88\%) \\
\hline \multirow[t]{5}{*}{ Dyspnoea } & Mild & $62(32 \%)$ & 72 (39\%) & $78(42 \%)$ & $73(40 \%)$ & $38(22 \%)$ & $38(22 \%)$ & $21(14 \%)$ & $24(15 \%)$ \\
\hline & Moderate & $78(41 \%)$ & $74(40 \%)$ & $28(15 \%)$ & $18(10 \%)$ & $11(6 \%)$ & $8(5 \%)$ & $4(3 \%)$ & $9(6 \%)$ \\
\hline & Severe & $19(10 \%)$ & $16(9 \%)$ & $2(1 \%)$ & $4(2 \%)$ & 0 & $1(<1 \%)$ & $1(1 \%)$ & $2(1 \%)$ \\
\hline & Total & $159(83 \%)$ & $162(87 \%)$ & 108 (58\%) & $95(52 \%)$ & $49(29 \%)$ & $47(28 \%)$ & $26(17 \%)$ & $35(22 \%)$ \\
\hline & Absent & $33(17 \%)$ & $25(13 \%)$ & 77 (42\%) & $86(48 \%)$ & $122(71 \%)$ & $123(72 \%)$ & 128 (83\%) & $121(78 \%)$ \\
\hline \multirow[t]{3}{*}{ Chest congestion } & Mild & $33(17 \%)$ & $31(17 \%)$ & 117 (63\%) & $118(65 \%)$ & $38(22 \%)$ & $47(28 \%)$ & $21(14 \%)$ & $15(10 \%)$ \\
\hline & Moderate & $137(71 \%)$ & $132(71 \%)$ & $21(11 \%)$ & $20(11 \%)$ & $5(3 \%)$ & $1(<1 \%)$ & $5(3 \%)$ & $7(4 \%)$ \\
\hline & Severe & $14(7 \%)$ & $18(10 \%)$ & $2(1 \%)$ & $4(2 \%)$ & $1(<1 \%)$ & $1(<1 \%)$ & $2(1 \%)$ & $1(<1 \%)$ \\
\hline
\end{tabular}


Table III. Clinical efficacy of grepafloxacin and clarithromycin in the treatment of patients with acute bacterial exacerbations of chronic bronchitis

\begin{tabular}{|c|c|c|}
\hline $\begin{array}{l}\text { Clinical outcome } \\
\text { at follow-up }\end{array}$ & $\begin{array}{l}\text { Grepafloxacin } \\
\text { (10 days) [no. } \\
(\%)]\end{array}$ & $\begin{array}{l}\text { Clarithromycin } \\
\text { (10 days) } \\
\text { [no. }(\%)]\end{array}$ \\
\hline Cure $(\mathrm{C})$ & $108(73)$ & $114(76)^{\mathrm{a}}$ \\
\hline Improvement (I) & $22(15)$ & $20(13)$ \\
\hline Satisfactory $(C+I)^{b}$ & $130(88)$ & $134(89)$ \\
\hline Failure (F) & $9(6)$ & $7(5)$ \\
\hline Recurrence (R) & $9(6)$ & $9(6)$ \\
\hline Unsatisfactory $(F+R)$ & $18(12)$ & $16(11)$ \\
\hline Total, evaluable patients & 148 & 150 \\
\hline Unevaluable patients & 44 & 37 \\
\hline Total, all patients & 192 & 187 \\
\hline \multicolumn{3}{|c|}{ a Percentage of evaluable patients. } \\
\hline \multicolumn{3}{|c|}{$\begin{array}{l}\text { b Comparison of satisfactory outcomes between groups demon- } \\
\text { strated equivalence, } 95 \% \text { confidence interval }=(-0.09,0.06) \\
p=0.69 \text {. }\end{array}$} \\
\hline
\end{tabular}

clarithromycin group at the first during-treatment visit.

Similarly, the percentage of patients with severe increased sputum production decreased from $16 \%$ at enrolment to $4 \%$ after 4 to 6 days of treatment (first during-treatment visit) in the grepafloxacin group. Similar rates of symptom improvement were observed in the clarithromycin group.

When clinical efficacy was analysed by organism for the five primary pathogens (H. parainfluenzae, $H$. influenzae, S. pneumoniae, $M$. catarrhalis and Staphylococcus aureus) isolated from patients enrolled in the trial, satisfactory clinical response rates for grepafloxacin were comparable with those for clarithromycin (table IV).

\section{Bacteriological Outcome}

Bacterial isolates were obtained from the pretreatment sputum specimens of 330 of $379(87 \%)$ study patients, and $254(67 \%)$ of the 379 patients enrolled were bacteriologically evaluable. The primary pathogens isolated were $H$. parainfluenzae (31\% of isolates), H. influenzae (18\%), M. catarrhalis $(6 \%)$, S. pneumoniae $(5 \%)$ and $S$. aureus (4\%). $19 \%$ of the $H$. influenzae isolates and $94 \%$ of the $M$. catarrhalis isolates tested for 


\begin{tabular}{|c|c|c|c|c|c|c|c|c|c|}
\hline & Total & $184(96 \%)$ & $181(97 \%)$ & $140(76 \%)$ & $142(78 \%)$ & $44(26 \%)$ & $49(29 \%)$ & $28(18 \%)$ & $23(15 \%)$ \\
\hline & Absent & $8(4 \%)$ & $6(3 \%)$ & $45(24 \%)$ & $39(22 \%)$ & $127(74 \%)$ & $121(71 \%)$ & $126(82 \%)$ & $133(85 \%)$ \\
\hline \multirow[t]{5}{*}{ Fever } & Mild & $9(5 \%)$ & $7(4 \%)$ & $3(2 \%)$ & 0 & $2(1 \%)$ & 0 & $1(<1 \%)$ & $1(<1 \%)$ \\
\hline & Moderate & $6(3 \%)$ & $3(2 \%)$ & 0 & 0 & 0 & 0 & 0 & $1(<1 \%)$ \\
\hline & Severe & 0 & 0 & 0 & 0 & 0 & 0 & 0 & 0 \\
\hline & Total & 15 (8\%) & $10(5 \%)$ & $3(2 \%)$ & 0 & $2(1 \%)$ & 0 & $1(<1 \%)$ & $2(1 \%)$ \\
\hline & Absent & $177(92 \%)$ & 177 (95\%) & 182 (98\%) & $181(100 \%)$ & 169 (99\%) & $170(100 \%)$ & 153 (>99\%) & 154 (99\%) \\
\hline \multirow[t]{5}{*}{ Chills } & Mild & $51(27 \%)$ & $43(23 \%)$ & $16(9 \%)$ & $12(7 \%)$ & $5(3 \%)$ & $5(3 \%)$ & $2(1 \%)$ & $2(1 \%)$ \\
\hline & Moderate & 15 (8\%) & $11(6 \%)$ & $1(<1 \%)$ & $1(<1 \%)$ & 0 & $2(1 \%)$ & 0 & $2(1 \%)$ \\
\hline & Severe & $2(1 \%)$ & $2(1 \%)$ & $1(<1 \%)$ & $1(<1 \%)$ & 0 & 0 & 0 & $1(<1 \%)$ \\
\hline & Total & $68(36 \%)$ & $56(30 \%)$ & $18(10 \%)$ & $14(8 \%)$ & $5(3 \%)$ & $7(4 \%)$ & $2(1 \%)$ & $5(3 \%)$ \\
\hline & Absent & $124(64 \%)$ & $131(70 \%)$ & 167 (90\%) & 167 (92\%) & $166(97 \%)$ & $163(96 \%)$ & 152 (99\%) & $151(97 \%)$ \\
\hline
\end{tabular}



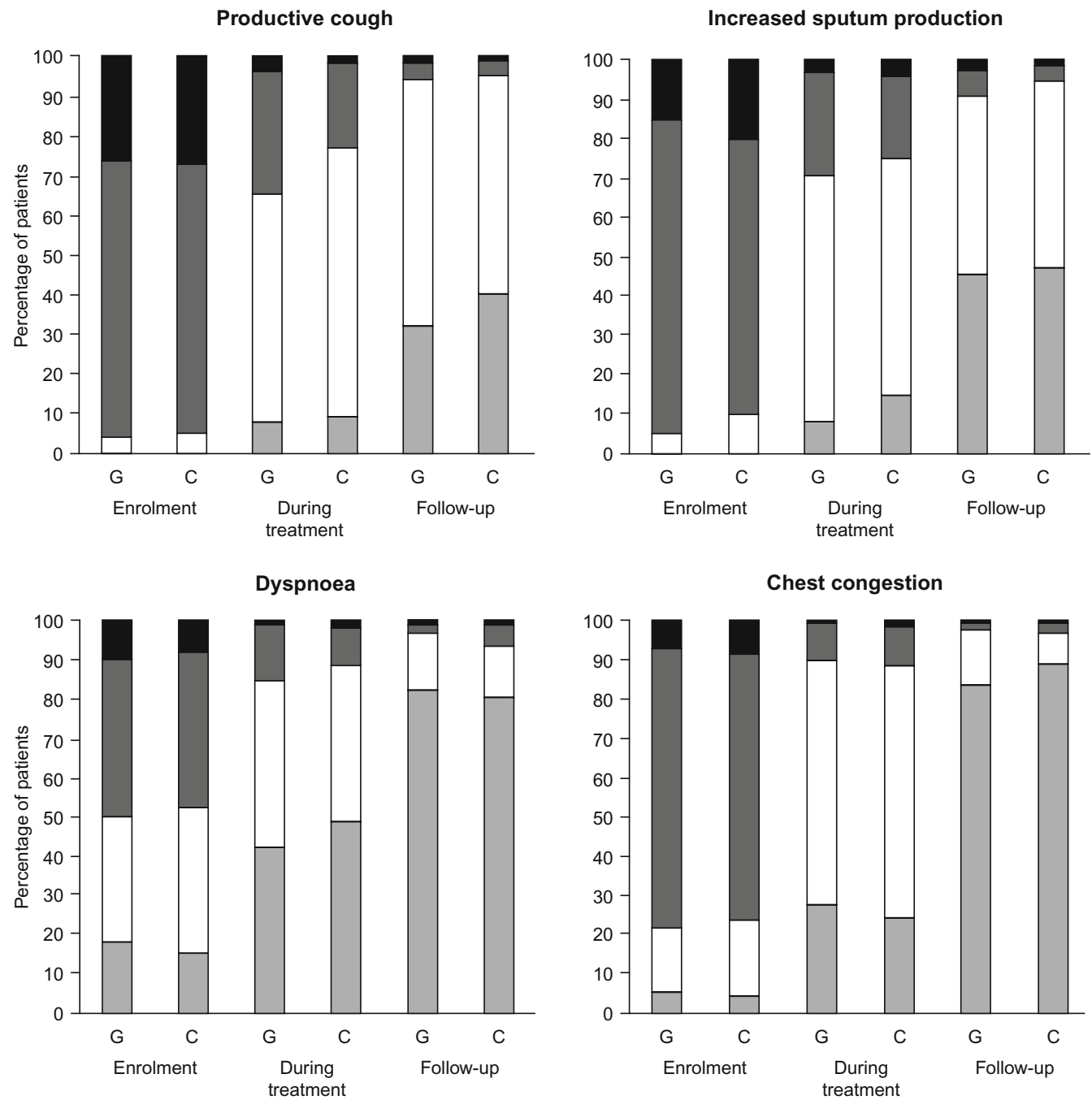

Fig. 1. Severity of symptoms in clinically evaluable patients with acute bacterial exacerbations of chronic bronchitis in the grepafloxacin (G) or clarithromycin (C) group at the time of enrolment, at the 4- to 6-day during-treatment visit, and at the 21- to 24-day post-treatment follow-up visit.

$\beta$-lactamase production were positive. Of the 354 pathogens isolated from the 330 patients, greater than $99 \%$ were susceptible to grepafloxacin, while $81 \%$ were susceptible to clarithromycin (table V).

Eight of the 28 (29\%) S. pneumoniae isolates demonstrated resistance to penicillin, with five of these eight (63\%) showing intermediate resistance and the remaining three (37\%) being highly resistant to penicillin. All S. pneumoniae isolates demonstrated susceptibility to grepafloxacin, while five of the $28(18 \%)$ isolates were highly resistant to clarithromycin. 
Table IV. Clinical efficacy of grepafloxacin and clarithromycin analysed by organism in evaluable patients at follow-up

\begin{tabular}{lcc}
\hline Organism & \multicolumn{2}{c}{ Satisfactory clinical outcome ${ }^{\mathrm{a}}$} \\
\cline { 2 - 3 } & $\begin{array}{l}\text { grepafloxacin } \\
(10 \text { days })\end{array}$ & $\begin{array}{c}\text { clarithromycin } \\
(10 \text { days })\end{array}$ \\
& {$[$ no. $(\%)]$} & [no. $(\%)]$ \\
\hline Streptococcus pneumoniae & $6 / 7(86)$ & $7 / 7(100)$ \\
Haemophilus parainfluenzae & $67 / 75(89)$ & $65 / 71(92)$ \\
H. influenzae & $31 / 33(94)$ & $28 / 32(88)$ \\
Moraxella catarrhalis & $13 / 13(100)$ & $9 / 10(90)$ \\
Staphylococcus aureus & $8 / 10(80)$ & $8 / 9(89)$ \\
\hline a Satisfactory clinical outcome includes clinical cure and clinical \\
\multicolumn{3}{l}{ improvement. } \\
\hline
\end{tabular}

When bacteriological outcomes were analysed by organism, satisfactory responses were seen in $86 \%(6 / 7)$ and $83 \%(5 / 6)$ of $S$. pneumoniae isolates in the grepafloxacin and clarithromycin groups, respectively. Satisfactory outcomes for $H$. para- influenzae were $87 \%(65 / 75)$ versus $83 \%(59 / 71)$ for the grepafloxacin and clarithromycin groups, respectively. For $H$. influenzae, $M$. catarrhalis and S. aureus satisfactory responses reported were $91 \%$ $(30 / 33)$ versus $75 \%(24 / 32), 100 \%(13 / 13)$ versus $60 \%(6 / 10)$, and $90 \%(9 / 10)$ versus $78 \%(7 / 9)$, respectively.

A satisfactory bacteriological response (cure or presumed cure) was obtained in $88 \%(113 / 129)$ and $78 \%(97 / 125)$ of bacteriologically evaluable patients treated with grepafloxacin or clarithromycin, respectively $(\mathrm{p}=0.04,95 \% \mathrm{CI}=0.00$, $0.20)$. Seven patients in the grepafloxacin group and 11 patients in the clarithromycin group were failures or presumed failures. Seven and 10 patients, respectively, in the grepafloxacin and clarithromycin groups were classified as cures

Table V. Antimicrobial susceptibility of pretreatment isolates of primary pathogens

\begin{tabular}{|c|c|c|c|c|c|}
\hline \multirow[t]{2}{*}{ Pathogen } & \multirow[t]{2}{*}{ Antimicrobial agent } & \multirow[t]{2}{*}{ No. } & \multicolumn{3}{|c|}{ Susceptibility frequencies [no. (\%)] } \\
\hline & & & susceptible & intermediate & resistant \\
\hline \multirow[t]{2}{*}{ Haemophilus influenzae } & Grepafloxacin & 96 & $96(100)$ & & \\
\hline & Clarithromycin & 96 & $81(84)$ & $8(8)$ & $7(7)$ \\
\hline \multirow[t]{3}{*}{ Streptococcus pneumoniae } & Grepafloxacin & 28 & $28(100)$ & & \\
\hline & Clarithromycin & 28 & $23(82)$ & & $5(18)$ \\
\hline & Penicillin & 28 & $20(71)$ & $5(18)$ & $3(11)$ \\
\hline \multirow[t]{2}{*}{ Moraxella catarrhalis } & Grepafloxacin & 32 & $32(100)$ & & \\
\hline & Clarithromycin & 32 & $32(100)$ & & \\
\hline \multirow[t]{2}{*}{ H. parainfluenzae } & Grepafloxacin & 173 & $173(100)$ & & \\
\hline & Clarithromycin & 173 & $129(75)$ & $30(17)$ & $14(8)$ \\
\hline \multirow[t]{2}{*}{ Staphylococcus aureus } & Grepafloxacin & 25 & $24(96)$ & & $1(4)$ \\
\hline & Clarithromycin & 25 & $21(84)$ & & $4(16)$ \\
\hline
\end{tabular}

Table VI. Summary of the most common ${ }^{a}$ drug-related adverse events reported by patients with acute bacterial exacerbations of chronic bronchitis treated with grepafloxacin or clarithromycin

\begin{tabular}{|c|c|c|c|}
\hline Adverse event ${ }^{b}$ & $\begin{array}{l}\text { Grepafloxacin } \\
\text { (10 days) } \\
{[n=192 ; \text { no. (\%)] }}\end{array}$ & $\begin{array}{l}\text { Clarithromycin } \\
\text { (10 days) } \\
{[\mathrm{n}=187 ; \text { no. }(\%)]}\end{array}$ & p-Value \\
\hline \multicolumn{4}{|l|}{ Gastrointestinal (GI) system } \\
\hline Total patients with one or more Gl events & $24(13)$ & $30(16)$ & 0.38 \\
\hline Diarrhoea/loose bowel movements & $7(4)$ & $9(5)$ & 0.62 \\
\hline Nausea & $10(5)$ & $8(4)$ & 0.81 \\
\hline Disturbance of sense of taste & $11(6)$ & $12(6)$ & 0.83 \\
\hline Abnormal/unusual taste & $9(5)$ & $19(10)$ & 0.05 \\
\hline Total patients with one or more drug-related adverse events & $48(25)$ & $62(33)$ & 0.09 \\
\hline \multicolumn{4}{|l|}{ a Occurring with an incidence of $5 \%$ or greater. } \\
\hline \multicolumn{4}{|c|}{ b Adverse events are not necessarily additive since some patients reported more than one adverse event. } \\
\hline \multicolumn{4}{|c|}{ c Treatment comparisons of incidence were performed using Fisher's exact test. Values less than 0.05 were significant. } \\
\hline
\end{tabular}


with superinfection, while one and seven patients, respectively, were failures with superinfection. One patient in the grepafloxacin group had a recurrence.

\section{Tolerability Evaluations}

There were no statistically significant differences in drug-related adverse events between patients in the two treatment groups (table VI). The most common drug-related adverse events were nausea, diarrhoea, taste disturbance and abnormal taste.

Six patients (3\%) in each treatment group withdrew from the study because of adverse events. In seven of these patients, the events were judged by the investigator to be drug related, including four patients in the grepafloxacin treatment group (drug-related adverse events included diarrhoea, dizziness, drowsiness, nausea, vomiting and skin rash) and three patients in the clarithromycin treatment group (drug-related adverse events included abnormal taste, nausea, feeding problems, gastrointestinal distress, skin rash and tinnitus). Five serious adverse events were reported, none of which were considered drug related.

\section{Discussion}

The results of this study indicated that oncedaily administration with grepafloxacin 400mg for 10 days is as well tolerated and clinically effective as twice-daily administration with clarithromycin $500 \mathrm{mg}$ for 10 days in the treatment of patients with ABECB.

The clinical cure or improvement rates reported at follow-up in this study ( 88 and $89 \%$ in the grepafloxacin and clarithromycin groups, respectively) were similar to those observed in previous clinical comparisons of 10-day treatments for ABECB with grepafloxacin and amoxicillin (82 vs $85 \%)^{[21]}$ and grepafloxacin and ciprofloxacin (87 vs $80 \%$ ). ${ }^{[22]}$ Collectively, these studies confirm the clinical efficacy of grepafloxacin in the treatment of ABECB.

Patients in the grepafloxacin group demonstrated marked improvement within 4 to 6 days after initiation of therapy (the first duringtreatment measurement) as indicated by substantial decreases in the incidence and severity of symptoms. Improvement continued and was maintained throughout the study. Improvements were comparable in the clarithromycin treatment group.

While the clinical efficacies of grepafloxacin and clarithromycin were equivalent in the present study, the bacteriological cure rates of the two treatments approached but did not meet the criteria for equivalence. When bacteriological success was assessed as a function of infecting organism in the present study, patients in the grepafloxacin treatment group showed microbiological cure rates comparable to those seen in the clarithromycin group for patients yielding $S$. pneumoniae or $H$. parainfluenzae.

Treatment with grepafloxacin $400 \mathrm{mg}$ once daily for 10 days was associated with a low incidence of drug-related adverse events similar to that seen with clarithromycin. The most common drugrelated adverse events reported in both treatment groups were nausea, diarrhoea, taste disturbance and abnormal taste. The majority of these were mild to moderate in severity and few patients withdrew from the study as a result of drug-related adverse events.

The choice of an oral antibiotic for the treatment of $\mathrm{ABECB}$ requires not only consideration of clinical and bacteriological efficacy and tolerability profile, but also consideration of dosage convenience. Patient compliance with oral antibiotic therapy is known to correlate with the dosage regimen. Mean compliance rates of 80,60 and $38 \%$ were found when oral antibiotics were administered once, twice and three times a day, respectively. ${ }^{[23]}$ Therefore, grepafloxacin $400 \mathrm{mg}$ once daily may have positive effects on patient adherence to therapy compared with antibiotics that require more frequent dose administration.

\section{Conclusions}

In conclusion, grepafloxacin $400 \mathrm{mg}$ once daily for 10 days was as well tolerated and clinically effective as a 10-day course of clarithromycin 500mg 
twice daily for patients with ABECB. Grepafloxacin was associated with a marked reduction in the proportion of patients with symptoms of ABECB and substantial improvement in the severity of symptoms within 4 to 6 days (the first during-treatment measurement) of beginning treatment.

The broad-spectrum antibacterial activity of grepafloxacin, including excellent activity against the major bacterial pathogens of the lower respiratory tract (Gram-positive, Gram-negative and atypical organisms), continued activity against multidrug-resistant isolates, as well as excellent penetration into lung tissues, supports its use in the treatment of this lower respiratory tract infection.

\section{Acknowledgements}

The authors thank the following investigators for their participation in the study: Malik Baz, MD, Fresno, CA; Kelly Black, MD, Phoenix, AZ; Mark Blatter, MD, Upper St Clair, PA; David R. Crittenden, MD, Fayetteville, AR; Gary Greenwald, MD, Palm Springs, CA; Stuart Levin, MD, Raleigh, NC; Nicholas Kuchmak, MD, Dallas, TX; Martin Levinson, MD, Willinboro, NJ; Michael McAdoo, MD, Milan, TN; William M. Shapiro, MD, San Diego, CA; Stephen R. Lewis, MD, Tampa, FL.

We also thank Patrice C. Ferriola, PhD, Glaxo Wellcome Inc., for editorial assistance. Funding for the study was provided by a grant from Glaxo Wellcome Inc. Grepafloxacin is licensed from Otsuka Pharmaceutical Co. Ltd, Japan.

\section{References}

1. Enright PL, Kronmal RA, Higgins MW, et al. Prevalence and correlates of respiratory symptoms and disease in the elderly. Cardiovascular Health Study. Chest 1994; 106: 827-34

2. Anthonisen NR, Manfreda J, Warren CP, et al. Antibiotic therapy in exacerbations of chronic obstructive pulmonary disease. Ann Intern Med 1987; 106: 196-204

3. Gump DW, Phillips CA, Forsyth BR, et al. Role of infection in chronic bronchitis. Am Rev Respir Dis 1976; 113: 465-74

4. Kayser FH. Changes in the spectrum of organisms causing respiratory tract infections: a review. Postgrad Med J 1992; 68: S17-23

5. Saint S, Bent S, Vittinghoff E, et al. Antibiotics in chronic obstructive pulmonary disease exacerbations - a meta-analysis. JAMA 1995; 273: 957-60

6. Thornsberry C. Emerging resistance in clinically important gram-positive cocci. West J Med 1996; 164: 28-32

7. Campbell G, Silberman R. Drug-resistant Streptococcus pneumoniae. Clin Infect Dis 1998; 26: 1188-95

8. Venkatsen P, Innes J. Antibiotic resistance in common acute respiratory pathogens. Thorax 1995; 50: 481-3

9. Thornsberry C, Ogilvie P, Kahn J, et al. Surveillance of antimicrobial resistance in Streptococcus pneumoniae, Haemophilus influenzae, and Moraxella catarrhalis in the United
States in 1996-1997 respiratory season. The Laboratory Investigator Group. Diagn Microbiol Infect Dis 1997; 29: 24957

10. Doern GV, Brueggemann A, Holley Jr HP, et al. Antimicrobial resistance of Streptococcus pneumoniae recovered from outpatients in the United States during the winter months of 1994 to 1995: results of a 30-center national surveillance study. Antimicrob Agents Chemother 1996; 40: 1208-13

11. Doern GV, Brueggemann AB, Pierce G, et al. Antibiotic resistance among clinical isolates of Haemophilus influenzae in the United States in 1994 and 1995 and detection of $\beta$ lactamase-positive strains resistant to amoxicillin-clavulanate: results of a national multicenter surveillance study. Antimicrob Agents Chemother 1997; 41: 292-7

12. Doern GV, Brueggemann AB, Pierce G, et al. Prevalence of antimicrobial resistance among 723 outpatient clinical isolates of Moraxella catarrhalis in the United States in 1994 and 1995: results of a 30-center national surveillance study. Antimicrob Agents Chemother 1996; 40: 2884-6

13. Doern GV. Trends in antimicrobial susceptibility of bacterial pathogens of the respiratory tract. Am J Med 1995; 99: 3S-7S

14. Imada $\mathrm{T}$, Miyazaki $\mathrm{S}$, Nishida $\mathrm{M}$, et al. In vitro and in vivo antibacterial activities of a new quinolone, OPC-17116. Antimicrob Agents Chemother 1992; 36: 573-9

15. Marco F, Jones RN, Hoban DJ, et al. In vitro activity of OPC17116 against more than 6000 consecutive clinical isolates: a multicentre international study. J Antimicrob Chemother 1994; 33: 647-54

16. Cook PJ, Andrews JM, Wise R, et al. Concentrations of OPC17116, a new fluoroquinolone antibacterial, in serum and lung compartments. J Antimicrob Chemother 1995; 35: 317-26

17. Efthymiopoulos C, Bramer SL, Maroli A. Pharmacokinetics of grepafloxacin after oral administration of single and repeat doses in healthy young males. Clin Pharmacokinet 1997; 33 Suppl. 1: 1-8

18. Peters D, Clissold S. Clarithromycin: a review of its antimicrobial activity. Pharmacokinet Prop Ther Potential 1992; 44: $117-64$

19. NCCLS. Performance Standards for Antimicrobial Disk Susceptibility Tests - 6th Edition; Approved Standard M2-A6 (ISBN 1-56238-308-6). National Committee for Clinical Laboratory Standards; Wayne, PA: 1997

20. NCCLS. Methods for Dilution Antimicrobial Susceptibility Tests for Bacteria That Grow Aerobically - 4th Edition; Approved Standard M7-A4 (ISBN 1-56238-309-4). National Committee for Clinical Laboratory Standards; Wayne, PA: 1997

21. Langan CE, Cranfield R, Breisch S, et al. Randomized, doubleblind study of grepafloxacin versus amoxycillin in patients with acute bacterial exacerbations of chronic bronchitis. J Antimicrob Chemother 1997; 40 Suppl. A: 63-72

22. Chodosh S, Lakshminarayan S, Swarz H, et al. Efficacy and safety of a 10-day course of 400 or 600 milligrams of grepafloxacin once daily for treatment of acute bacterial exacerbations of chronic bronchitis: comparison with a $10-$ day course of 500 milligrams of ciprofloxacin twice daily. Antimicrob Agents Chemother 1998; 42: 114-20

23. Sclar DA, Tartaglione TA, Fine MJ. Overview of issues related to medical compliance with implications for the outpatient management of infectious diseases. Infect Agents Dis 1994; 3: $266-73$

Correspondence and reprints: Dr C. Andrew DeAbate, Medical Research Center, 1020 Gravier Street, Suite 100, New Orleans, LA 70112, USA. 